\title{
Meditation as a Tool for Psychotherapy
}

\author{
Ven Sumedh Thero* \\ Chief Priest \& Founder Sumedh Bhoomi Buddha Vihar, Ambedkar Park, Jhansipura, Lalitpur, India
}

*Corresponding author: Ven Sumedh Thero, Chief Priest \& Founder Sumedh Bhoomi Buddha Vihar, Dr Ambedkar Park, Jhansipura, Lalitpur, India

\section{Introduction}

Buddhist meditation is the practice of meditation in Buddhism and Buddhist philosophy. It includes a variety of types of meditation. Core meditation techniques have been preserved in ancient Buddhist texts and have proliferated and diversified through teacher-student transmissions. Buddhists pursue meditation as part of the path toward Enlightenment and Nirvana.

[a] The closest words for meditation in the classical languages of Buddhism are bhāvanā

[b] and jhāna/dhyāna.

[c] Buddhist meditation techniques have become increasingly popular in the wider world, with many nonBuddhists taking them up for a variety of reasons. Buddhist meditation encompasses a variety of meditation techniques that aim to develop sati (mindfulness), samadhi(concentration), abhijñā (supramundanepowers), (supramundanepowers), samatha (tranquility), and vipassanā (insight). Specific Buddhist meditation techniques have also been used to remove unwholesome qualities thought to be impediments to spiritual liberation, such loving kindness to remove ill-will, hate, and anger, equanimity to remove mental clinging, and patikulamanasikara (meditations on the parts of the body) and marana sati (meditation on death and corpses) to remove sensual lust for the body and cultivate impermanence (anicca). Given the large number and diversity of traditional Buddhist meditation practices, this article primarily identifies authoritative contextual frameworks-both contemporary and canonical-for the variety of practices. For those seeking school-specific meditation information, it may be more appropriate to simply view the articles listed in the "See also" section below. While there are some similar meditative practices - such as breath meditation and various recollections (anussati)-that are used across Buddhist schools, there is also significant diversity. In the Theravada tradition alone, there are over fifty methods for developing mindfulness and forty for developing concentration, while in Tibetan Buddhism, there are thousands of visualization meditations. [d] Most classical and contemporary Buddhist meditation guides are school specific.

[e] Only a few teachers attempt to synthesize, crystallize and categorize practices from multiple Buddhist traditions.

\section{Pre-Buddhist India}

The two major traditions of meditative practice in pre-Buddhist India were the Jain ascetic practices and the various Vedic Brahmanical practices. There is still much debate in Buddhist studies regarding how much influence these two traditions had on the development of early Buddhist meditation. The early Buddhist texts mention that the Gautama trained under two teachers known as Ālāra Kālāma and Uddaka Rāmaputta, both of them taught formless jhanas or mental absorptions, a key practice of proper Buddhist meditation [1]. Alexander Wynne considers these figures historical persons associated with the doctrines of the early Upanishads [2]. Other practices which the Buddha undertook have been associated with the Jain ascetic tradition by the Indologist Johannes Bron khorst including extreme fasting and a forceful «meditation without breathing» [3]. According to the early texts, the Buddha rejected the more extreme Jain ascetic practices in favor of the middle way. The early Buddhist tradition also taught other meditation postures, such as the standing posture and the lion posture performed laying down on one side. Modern Buddhist studies has attempted to reconstruct the meditation practices of pre-sectarian Early Buddhism, mainly through philological and text critical methods using the early canonical texts [4]. There is no single consensus on how early Buddhists practiced meditation. This is partly because as Indologist Johannes Bronkhorst notes, the sources present «a variety of methods that do not always agree with each other [4]. "One example of this disagreement on meditative methods found in the early sources is outlined by Bronkhorst: The Vitakkasanthāna Sutta of the Majjhima Nikāya and its parallels in Chinese translation recommend the practicing monk to 'restrain his thought with his mind, to coerce and torment it'. 
Exactly the same words are used elsewhere in the Pāli canon (in the Mahāsaccaka Sutta, Bodhirājakumāra Sutta and Sañgārava Sutta) in order to describe the futile attempts of the Buddha before his enlightenment to reach liberation after the manner of the Jainas [4]. According to Bronkhorst, such practices which are

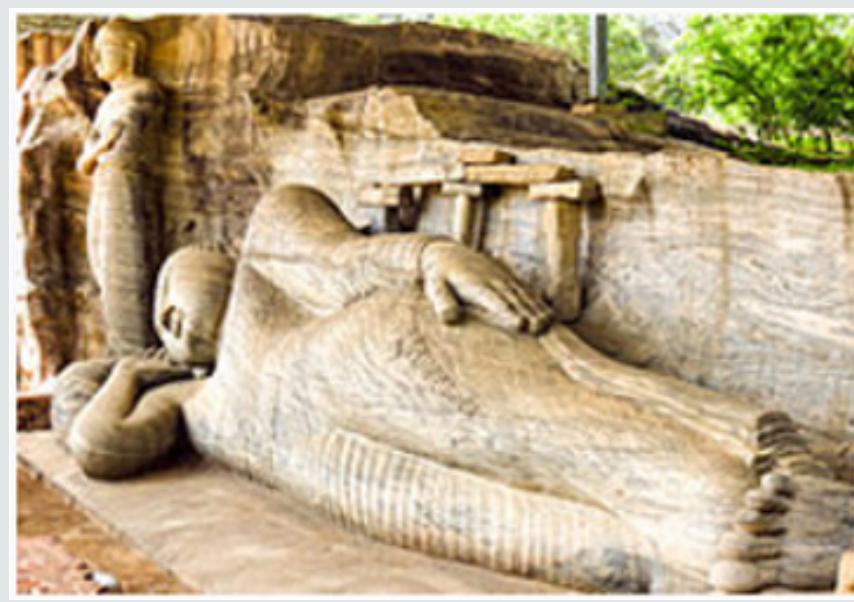

Figure 1: Early Buddhism.

According to Alexander Wynne, the Buddha taught a kind of meditation exemplified by the four dhyanas which he adopted from the Brahmin teachers Ālāra Kālāma and Uddaka Rāmaputta though he did not interpret them in the same Vedic cosmological way and rejected their Vedic goal (union with Brahman). The Buddha according to Wynne, radically transformed the practice of dhyana which he learned from these Brahmins which «consisted of the adaptation of the old yogic techniques to the practice of mindfulness and attainment of insight» [5]. For Wynne, this idea that liberation required not just meditation, but an act of insight was radically different than the Brahminic meditation, "where it was thought that the yogin must be without any mental activity at all, 'like a log of wood' [6].

\section{Context}

Most Buddhist traditions recognize that the path to Enlightenment entails three types of training: virtue (sīla); meditation (samadhi); and, wisdom (paññā). [f] Thus, meditative prowess alone is not sufficient; it is but one part of the path. In other words, in Buddhism, in tandem with mental cultivation, ethical development and wise understanding are also necessary for the attainment of the highest goal [7].

In terms of early traditions as found in the vast Pāli Canon and the Āgamas, meditation can be contextualized as part of the Noble Eightfold Path, explicitly in regard to:

a) Right Mindfulness (samma sati)-exemplified by the Buddha's Four Foundations of Mindfulness (see Satipatthana Sutta).

b) Right Concentration (samma samadhi) - culminating in jhana (meditative absorption) through the meditative development of samatha [8].

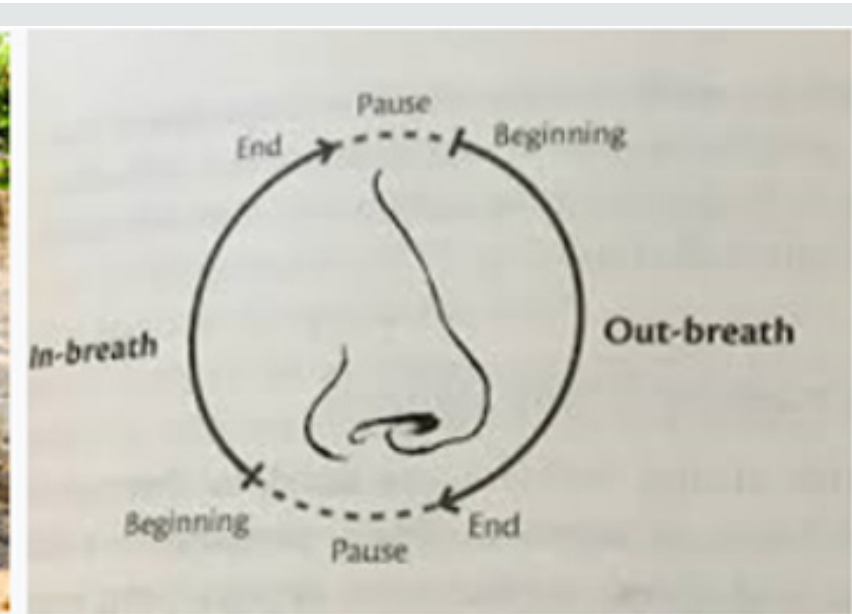

based on a "suppression of activity" are not authentically Buddhist, but were later adopted from the Jains by the Buddhist community. Bronkhorst's thesis is that the authentic Buddhist meditation is mainly based on the four dhyanas which lead to the destruction of the asavas as well as the practice of mindfulness (sati) [4] (Figure 1). a) Right View (samma ditthi) : embodying wisdom traditionally attained through the meditative development of vipassana founded on samatha ${ }^{[g]}$.

Classic texts in the Pali literature enumerating meditative subjects include the Satipatthana Sutta (MN 10) and the Visuddhimagga's Part II, "Concentration" (Samadhi).

\section{Serenity and insight:}

The Buddha is said to have identified two paramount mental qualities that arise from wholesome meditative practice:

a) "serenity" or "tranquillity" (Pali: samatha) which steadies, composes, unifies and concentrates the mind;

b) "insight" (Pali: vipassanā) which enables one to see, explore and discern "formations" (conditioned phenomena based on the five aggregates) [h].

Through the meditative development of serenity, one is able to suppress obscuring hindrances; and, with the suppression of the hindrances, it is through the meditative development of insight that one gains liberating wisdom [9]. Moreover, the Buddha is said to have extolled serenity and insight as conduits for attaining Nibbana (Pali; Skt.: Nirvana), the unconditioned state as in the "Kimsuka Tree Sutta» (SN 35.245), where the Buddha provides an elaborate metaphor in which serenity and insight are "the swift pair of messengers» who deliver the message of Nibbana via the Noble Eightfold Path [i].

In the "Four Ways to Arahantship Sutta" Ven. Ananda reports that people attain arahantship using serenity and insight in one of three ways:

a) they develop serenity and then insight (Pali: samathapubbangamam vipassanam) 
b) they develop insight and then serenity (Pali: vipassanapubbangamam samatham $\}\{$ While the Nikayas identify that the pursuit of vipassana can precede the pursuit of samatha, a fruitful vipassana-oriented practice must still be based upon the achievement of stabilizing "access concentration" (Pali: upacara samadhi).\}\}

c) they develop serenity and insight in tandem (Pali: samathavipassanam yuganaddham) as in, for instance, obtaining the first jhana, and then seeing in the associated aggregates the three marks of existence, before proceeding to the second jhana [10].

In the Pali canon, the Buddha never mentions independent samatha and vipassana meditation practices; instead, samatha and vipassana are two qualities of mind to be developed through meditation. ${ }^{[i]}$ Nonetheless, some meditation practices (such as contemplation of a kasina object) favor the development of samatha, others are conducive to the development of vipassana

Table 1: Jhānañga of The First Four Jhāna. (such as contemplation of the aggregates), while others (such as mindfulness of breathing) are classically used for developing both mental qualities [11].

\section{Dhyāna/Jhāna Dhyāna in Buddhism}

Many scholars of early Buddhism such as Vetter, Bronkhorst and Anālayo see the practice of absorption (Pāli: jhāna, Sanskrit: dhyāna) as central to the meditation of Early Buddhism [12-14]. It is a peaceful and happy mental state, in which one is secluded from sensual pleasures and conceptual thinking. According to Anālayo the jhanas are crucial meditative states which lead to the abandonment of hindrances such as lust and aversion however they are not sufficient for the attainment of liberating insight and some early texts also warn meditators against becoming attached to them and therefore forgetting the need for the further practice of insight [15]. There are said to be four form jhanas or meditative absorptions, each one more subtle and refined (Table 1).

\begin{tabular}{|c|c|c|c|c|c|c|}
\hline \multirow{2}{*}{ Jhāna } & Vitakka & Vicāra & Pīti & Sukha & Ekaggatā & Upekkhā \\
\hline & (Mental Application) & (Sustaining) & (Rapture) & (bliss) & (Unification of Mind) & (Equanimity) \\
\hline $1^{\text {st }}$ jhāna & $\mathscr{J}$ & $\downarrow$ & $\downarrow$ & $\mathscr{J}$ & 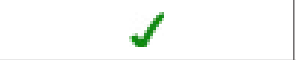 & $x$ \\
\hline $2^{\text {nd }}$ jhāna & $x$ & $\mathbf{x}$ & $\mathcal{J}$ & $\mathcal{J}$ & $\mathcal{J}$ & $x$ \\
\hline $3^{\text {rd }}$ jhāna & $x$ & $x$ & $x$ & $\checkmark$ & $\checkmark$ & $x$ \\
\hline $4^{\text {th }}$ jhāna & $\mathbf{x}$ & $\mathbf{x}$ & $x$ & x & $\downarrow$ & $\mathcal{J}$ \\
\hline
\end{tabular}

\section{They are Characterized by Several Factors called Jhānañga (Sanskrit: dhyānāñga):}

Various early sources mention the practice of insight after having achieved jhana. According to Anālayo, two interpretations of this material is possible, "either one undertakes such insight contemplation while still being in the attainment, or else one does so retrospectively, after having emerged from the absorption itself but while still being in a mental condition close to it in concentrative depth [16]." The position that insight can be practiced from within jhana according to the early texts is endorsed by Gunaratna, Crangle and Shankaman [17-19]. Anālayo meanwhile argues that the evidence from the early texts suggest that "contemplation of the impermanent nature of the mental constituents of an absorption takes place before or on emerging from the attainment" [20].

Apart from the four rūpajhānas, there are also meditative attainments which were later called by the tradition the arūpajhānas, though the early texts do not use the term dhyana for them, calling them āyatana (dimension, sphere, base). They are:

a) The Dimension of infinite space (Pali ākāsānañcāyatana, Skt. ākāśānantyāyatana),

b) The Dimension of infinite consciousness (Pali viññāṇañcāyatana, Skt. vijñānānantyāyatana),

c) The Dimension of infinite nothingness (Pali ākiñcaññāyatana, Skt. ākiṃcanyāyatana),

d) The Dimension of neither perception nor non-perception (Pali nevasaññānāsaññāyatana,
Skt. naivasaṃjñānāsaṃjñāyatana).

e) Nirodha-samāpatti, also called saññā-vedayitanirodha, 'extinction of feeling and perception'.

Illustration of mindfulness of death using corpses in a charnel ground, a subset of mindfulness of the body, the first satipatthana. From an early $20^{\text {th }}$ century manuscript found in Chaiya District, Surat Thani Province, Thailand [21]. An important quality to be cultivated by a Buddhist meditator is mindfulness (sati). Mindfulness is a polyvalent term which refers to remembering, recollecting and "bearing in mind". It also relates to remembering the teachings of the Buddha and knowing how these teachings relate to one's experiences. The Buddhist texts mention different kinds of mindfulness practice. According to Bronkhorst, there were originally two kinds of mindfulness, "observations of the positions of the body" and the 4 satipatțhānas which constituted formal meditation [22]. Bhikkhu Sujato and Bronkhorst both argue that the mindfulness of the positions of the body wasn't originally part of the four satipatthana formula but was later added to it in some texts [23]. In the Pali Satipatthana Sutta and its parallels as well as numerous other early Buddhist texts, the Buddha identifies four foundations for mindfulness (satipațthānas): the body (including the four elements, the parts of the body, and death), feelings (vedana), mind (citta) and phenomena or principles (dhammas), such as the five hindrances and the seven factors of enlightenment. Different early texts give different enumerations of these four mindfulness practices. Meditation on these subjects is said to develop insight [24] Figure 2. 


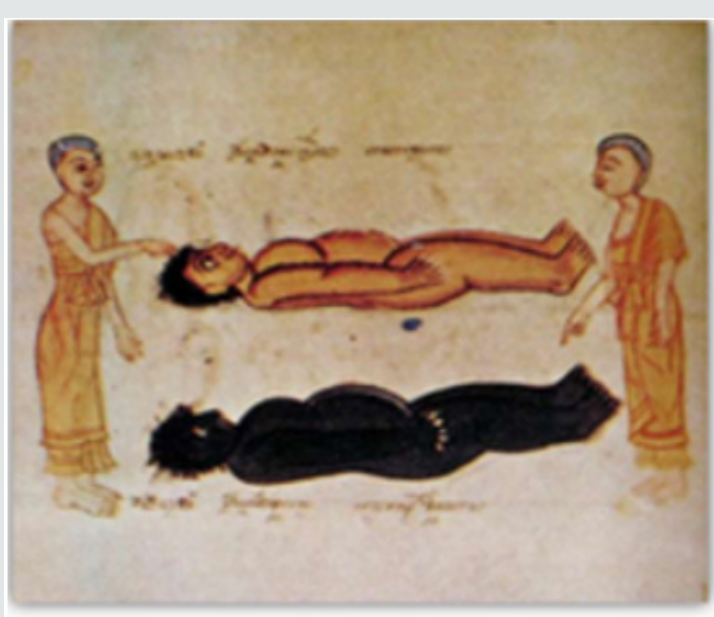

Figure 2: Mindfulness and Satipatthana.

\section{Brahmavihāra:}

Another important meditation in the early sources are the four Brahmavihāra (divine abodes) which are said to lead to cetovimutti, a "liberation of the mind" [25] . The four Brahmavihāra are:

a. Loving-kindness (Pāli: mettā, Sanskrit: maitrī) is active good will towards all $[26,27]$;

b. Compassion (Pāli and Sanskrit: karunāa) results from metta, it is identifying the suffering of others as one's own [26,27];

c. Empathetic joy (Pāli and Sanskrit: muditā): is the feeling of joy because others are happy, even if one did not contribute to it, it is a form of sympathetic joy [26];

d. Equanimity (Pāli: upekkhā, Sanskrit: upekșā): is evenmindedness and serenity, treating everyone impartially [26,27].

Buddhaghosa with three copies of Visuddhimagga, Kelaniya Raja Maha Vihara the oldest material of the Theravada tradition on meditation can be found in the Pali Nikayas and in texts such as the Patisambhidamagga which provide commentary to meditation suttas like the Anapanasati sutta. An early Theravada meditation manual is the Vimuttimagga ('Path of Freedom', $1^{\text {st }}$ or $2^{\text {nd }}$ century) [30]. The most influential presentation though, is that of the 5th Century Visuddhimagga ('Path of Purification') of Buddhaghoșa, which describes forty meditation subjects. Almost all of these are

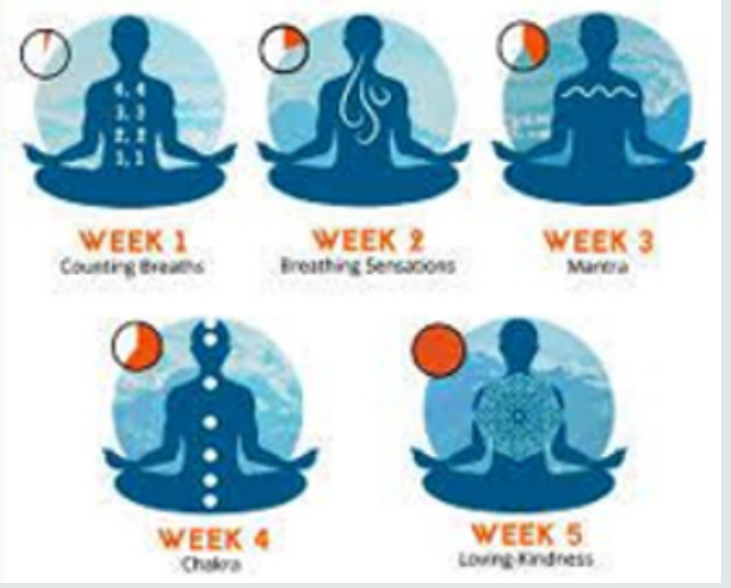

described in the early texts [31]. Buddhaghoșa also seems to have been influenced by the earlier Vimuttimagga in his presentation [32]. Buddhaghoșa advises that, for the purpose of developing concentration and consciousness, a person should "apprehend from among the forty meditation subjects one that suits his own temperament" with the advice of a "good friend" (kalyāna-mittatā) who is knowledgeable in the different meditation subjects ( $\mathrm{Ch}$. III, § 28) [33]. Buddhaghoșa subsequently elaborates on the forty meditation subjects as follows (Ch. III, §104; Chs. IV-XI) [34]: Ten kasinas: earth, water, fire, air, blue, yellow, red, white, light, and "limited-space".

a) ten kinds of foulness: "the bloated, the livid, the festering, the cut-up, the gnawed, the scattered, the hacked and scattered, the bleeding, the worm-infested, and a skeleton".

b) ten recollections: Buddhānussati, the Dhamma, the Sangha, virtue, generosity, the virtues of deities, death (see the Upajjhatthana Sutta), the body, the breath (see anapanasati), and peace (see Nibbana).

c) four divine abodes: mettā, karuṇā, mudita, and upekkha.

d) four immaterial states: boundless space, boundless perception, nothingness, and neither perception nor nonperception.

e) one perception (of "repulsiveness in nutriment")

f) one "defining" (that is, the four elements)
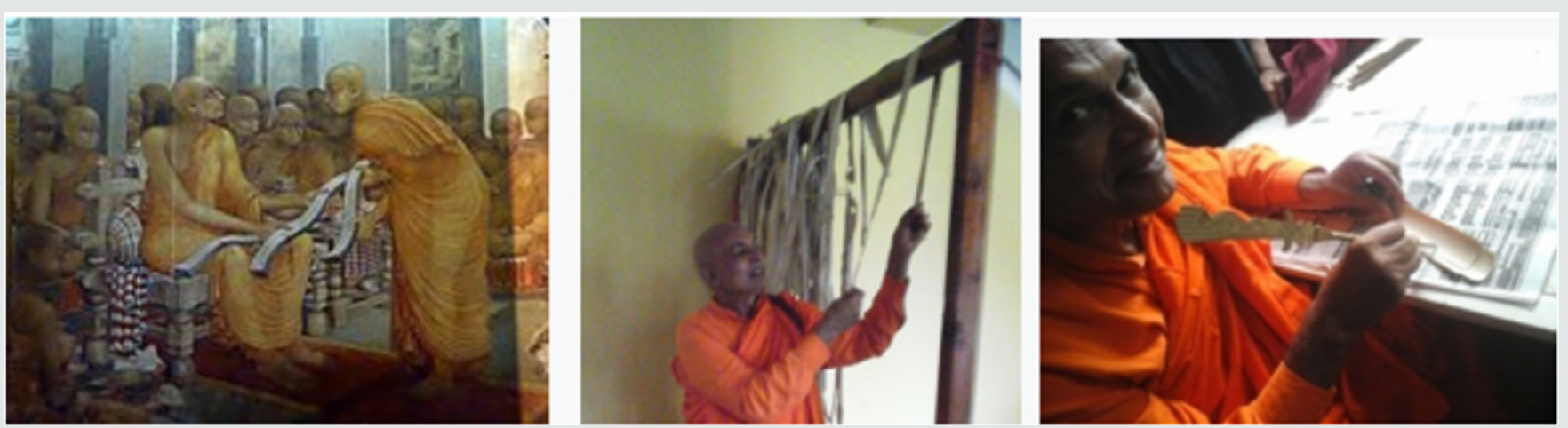

Figure 3: Theravadatradition 
When one overlays Buddhaghosa's 40 meditative subjects for the development of concentration with the Buddha's foundations of mindfulness, three practices are found to be in common: breath meditation, foulness meditation (which is similar to the Sattipatthana Sutta's cemetery contemplations, and to contemplation of bodily repulsiveness), and contemplation of the four elements. According to Pali commentaries, breath meditation can lead one to the equanimous fourth jhanic absorption. Contemplation of foulness can lead to the attainment of the first jhana, and contemplation of the four elements culminates in prejhana access concentration [35] (Figure 3).

The practice of meditation by Buddhistlaypersons is a key feature of the modern vipassana movement. Particularly influential from the twentieth century onward has been the "New Burmese Method" or "Vipassanā School" approach to samathaand vipassanā developed by Mingun Sayadaw and U Nārada and popularized by Mahasi Sayadaw. Here samatha is considered an optional but not necessary component of the practice-vipassanā is possible without it. Another Burmese method, derived from Ledi Sayadaw via Ba Khin and S. N. Goenka, takes a similar approach. Other Burmese traditions popularized in the west, notably that of Pa Auk Sayadaw, uphold the emphasis on samatha explicit in the commentarial tradition of the Visuddhimagga. These Burmese traditions have been particularly influential on the Western Vipassana movement (also called «Insight meditation There are also other less well known Burmese meditation methods, such as the system developed by $\mathrm{U}$ Vimala, which focuses on knowledge of dependent origination and cittanupassana (mindfulness of the mind) [36] . Likewise, Sayadaw $\mathrm{U}$ Tejaniya's method also focuses on mindfulness of the mind. Also influential is the Thai Forest Tradition deriving from Mun Bhuridatta and popularized by Ajahn Chah, which, in contrast, stresses the inseparability of the two practices, and the essential necessity of both practices. Other noted practitioners in this tradition include Ajahn Thateand Ajahn Maha Bua, among others[37]. There are other forms of Thai Buddhist meditation associated with particular teachers, including Buddhadasa Bhikkhu's presentation of anapanasati, Ajahn Lee's breath meditation method (which influenced his American student Thanissaro) and the "dynamic meditation" of Luangpor Teean Cittasubho [38]. There are other less mainstream forms of Theravada meditation practiced in Thailand which include the vijja dhammakaya meditationdeveloped by Lung $\mathrm{Pu}$ Sodh Candasaro and the meditation of former supreme patriarch Suk Kai Thuean. Newell notes that these two forms of modern Thai meditation share certain features in common with tantric practices such as the use of visualizations and centrality of maps of the body. A less common type of meditation is practiced in Cambodia and Laos by followers of Borān kammațthāna (‘ancient practices)) tradition. This form of meditation includes the use of mantras and visualizations.

\section{Sarvāstivāda}

The now defunct Sarvāstivāda tradition and its related subschools like the Sautrāntika and the Vaibhāṣika were the most influential Buddhists in North India and Central Asia. Their highly complex Abhidharma treatises such as the Mahavibhasa, the Sravakabhumi and the Abhidharmakosha contain new developments in meditative theory which are a major influence on meditation as practiced in East Asian Mahayana and Tibetan Buddhism. Individuals known as yogācāras (yoga practitioners) were influential in the development of Sarvāstivāda meditation praxis and some modern scholars such as Yin Shun believe they were also influential in the development of Mahayana meditation [39]. According to KL Dhammajoti, the Sarvāstivāda meditation practitioner begins with samatha meditations, divided into the fivefold mental stillings, each being recommended as useful for particular personality types:

contemplation on the impure (asubhabhavana), for the greedy type person.

A. Meditation on loving kindness (maitri), for the hateful type

B. contemplation on conditioned co-arising, for the deluded type

C. contemplation on the division of the dhatus, for the conceited type

D. mindfulness of breathing (anapanasmrti), for the distracted type [40].

Contemplation of the impure and mindfulness of breathing was particularly important in this system and they were known as the 'gateways to immortality' (amrta-dvāra) [41] The Sarvāstivāda system practiced breath meditation using the same sixteen aspect model used in the anapanasati sutta and also introduced a unique six aspect system which consists of:

a. counting the breaths up to ten

b. following the breath as it enters through the nose throughout the body

c. fixing the mind on the breath

d. observing the breath at various locations

e. modifying is related to the practice of the four applications of mindfulness and

\section{f. purifying stage of the arising of insight [41].}

This six fold breathing meditation method was influential in East Asia and expanded upon by the Chinese Tiantai meditation master Zhiyi [42] . After the practitioner has achieved tranquility, Sarvāstivāda Abhidharma then recommends one proceeds to practice the four applications of mindfulness (smrti-upasthāna) in two ways. First they contemplate each specific characteristic of the four applications of mindfulness and then they contemplate all four collectively [43]. In spite of this systematic division of samatha and vipasyana, the Sarvāstivāda Abhidharmikas held that the two practices are not mutually exclusive. The Mahavibhasa for example remarks that, regarding the six aspects of mindfulness of breathing, "there is no fixed rule here - all may come under samatha or all may come under vipasyana [44]." The Sarvāstivāda Abhidharmikas also held that attaining the dhyānas was necessary for the development of insight and wisdom [44]. 
Japanese wood statue of Asanga, a scholar who is believed to have contributed significantly to the development of the Yogacarabhumi, a Mahayana compendium of Buddhist praxis Mahāyāna Buddhism includes numerous schools of practice, which each draw upon various Buddhist sūtras, philosophical treatises, and commentaries. Accordingly, each school has its own meditation methods for the purpose of developing samādhi and prajñā, with the goal of ultimately attaining enlightenment. Nevertheless, each has its own emphasis, mode of expression, and philosophical outlook. In his classic book on meditation of the various Chinese Buddhist traditions, Charles Luk writes, "The Buddha Dharma is useless if it is not put into actual practice, because if we do not have personal experience of it, it will be alien to us and we will never awaken to it in spite of our book learning [45]." Nan Huaijin echoed similar sentiments about the importance of meditation by remarking, "Intellectual reasoning is just another spinning of the sixth consciousness, whereas the practice of meditation is the true entry into the Dharma [46]."

Initially, Mahayana Buddhists in India and East Asia practiced meditation in a similar way to that of the Sarvāstivāda school outlined above. One of the major Indian Mahayana treatises on meditation practice is the Yogacara bhumi (compiled circa late $4^{\text {th }}$ century), a compendium of texts which includes within it the Sarvāstivāda Sravakabhūmi (c. $2^{\text {nd }}-3^{\text {rd }}$ entury) as well as the Mahayana Bodhisattvabhūmi (c. $3^{\text {rd }}$ century) [47]. The works of the Chinese translator An Shigao (147-168 CE) are some of the earliest meditation texts used by Chinese Buddhism and their focus is mindfulness of breathing (annabanna), these texts are known as the Dhyāna sutras [48]. The Chinese translator and scholar Kumarajiva (344-413 CE) transmitted a meditation treatise titled The Sūtra Concerned with Samādhi in Sitting Meditation (T.614, K.991) which teaches the Sarvāstivāda system of fivefold mental stillings [49].

\section{Meditation in the Pure Land School: Mindfulness of Amitābha Buddha}

In Pure Land Buddhism, repeating the name of Amitābha is traditionally a form of mindfulness of theBuddha(Skt. buddhānusmṛti). This term was translated into Chinese as nianfo (Chinese), by which it is popularly known in English. The practice is described as calling the buddha to mind by repeating his name, to enable the practitioner to bring all his or her attention upon that buddha (samādhi) [50]. This may be done vocally or mentally, and with or without the use of Buddhist prayer beads. Those who practice this method often commit to a fixed set of repetitions per day, often from 50,000 to over 500,000. According to tradition, the second patriarch of the Pure Land school, Shandao, is said to have practiced this day and night without interruption, each time emitting light from his mouth. Therefore, he was bestowed with the title "Great Master of Light" by Emperor Gaozong of Tang [51]. In addition, in Chinese Buddhism there is a related practice called the "dual path of Chán and Pure Land cultivation», which is also called the "dual path of emptiness and existence [52]." As taught by Venerable Nan Huaijin, the name of Amitābha Buddha is recited slowly, and the mind is emptied out after each repetition. When idle thoughts arise, the phrase is repeated to clear them. With constant practice, the mind can remain peacefully in emptiness, culminating in the attainment of samādhi.

\section{Pure Land Rebirth Dhāranī}

Repeating the Pure Land Rebirth dhāraṇi is another method in Pure Land Buddhism. Similar to the mindfulness practice of repeating the name of Amitābha Buddha, this dhāraṇi is another method of meditation and recitation in Pure Land Buddhism. The repetition of this dhāranī is said to be very popular among traditional Chinese Buddhists [53]. It is traditionally preserved in Sanskrit, and it is said that when a devotee succeeds in realizing singleness of mind by repeating a mantra, its true and profound meaning will be clearly revealed.

a) namo amitābhāya tathāgatāya tadyathā

b) amṛtabhave amṛtasambhave

c) amṛtavikrānte amṛtavikrāntagāmini

d) gagana kīrtīchare svāhā

\section{Visualization Methods}

Another practice found in Pure Land Buddhism is meditative contemplation and visualization of Amitābha, his attendant bodhisattvas, and the Pure Land. The basis of this is found in the Amitāyurdhyāna Sūtra ("Amitābha Meditation Sūtra”), in which the Buddha describes to Queen Vaidehi the practices of thirteen progressive visualization methods, corresponding to the attainment of various levels of rebirth in the Pure Land [54]. Visualization practises for Amitābha are popular among esoteric Buddhist sects, such as Japanese Shingon Buddhism.

\section{Meditation in the Chán/Zen school: Pointing to the Nature of the Mind}

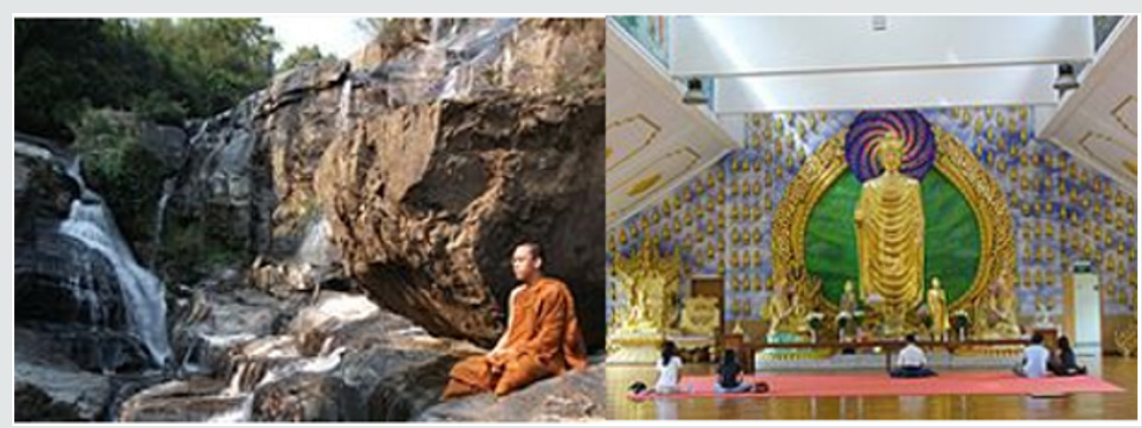

Figure 4: In Contemporary Theravada. 
In the earliest traditions of Zen, it is said that there was no formal method of meditation. Instead, the teacher would use various didactic methods to point to the true nature of the mind, also known as Buddha-nature. This method is referred to as the "Mind Dharma", and exemplified in the story of Śākyamuni Buddha holding up a flower silently, and Mahākāśyapa smiling as he understood. Figure 4 A traditional formula of this is, "Chán points directly to the human mind, to enable people to see their true nature and become buddhas [55]." In the early era of the Chán school, there was no fixed method or ple formula for teaching meditation, and all instructions were simply heuristic methods; therefore the Chán school was called the "Gateless Gate [56]."

\section{Contemplating Meditation Cases}

It is said traditionally that when the minds of people in society became more complicated and when they could not make progress so easily, the masters of the Chán school were forced to change their methods [57]. These involved particular words and phrases, shouts, roars of laughter, sighs, gestures, or blows from a staff. These were all meant to awaken the student to the essential truth of the mind, and were later called gōng'àn , or kōan in Japanese. These didactic phrases and methods were to be contemplated, and example of such a device is a phrase that turns around the practice of mindfulness: "Who is being mindful of the Buddha?» [58] The teachers all always instructed their students to give rise to a gentle feeling of doubt while practicing, so as to strip the mind of seeing, hearing, feeling, and knowing, and ensure its constant rest and undisturbed condition [59]. Charles Luk explains the essential function of contemplating such a meditation case with doubt: Since the student cannot stop all his thoughts at one stroke, he is taught to use this poison-against-poison device to realize singleness of thought, which is fundamentally wrong but will disappear when it falls into disuse, and gives way to singleness of mind, which is a precondition of the realization of the self-mind for the perception of self-nature and attainment of Bodhi [60] Figure 5.

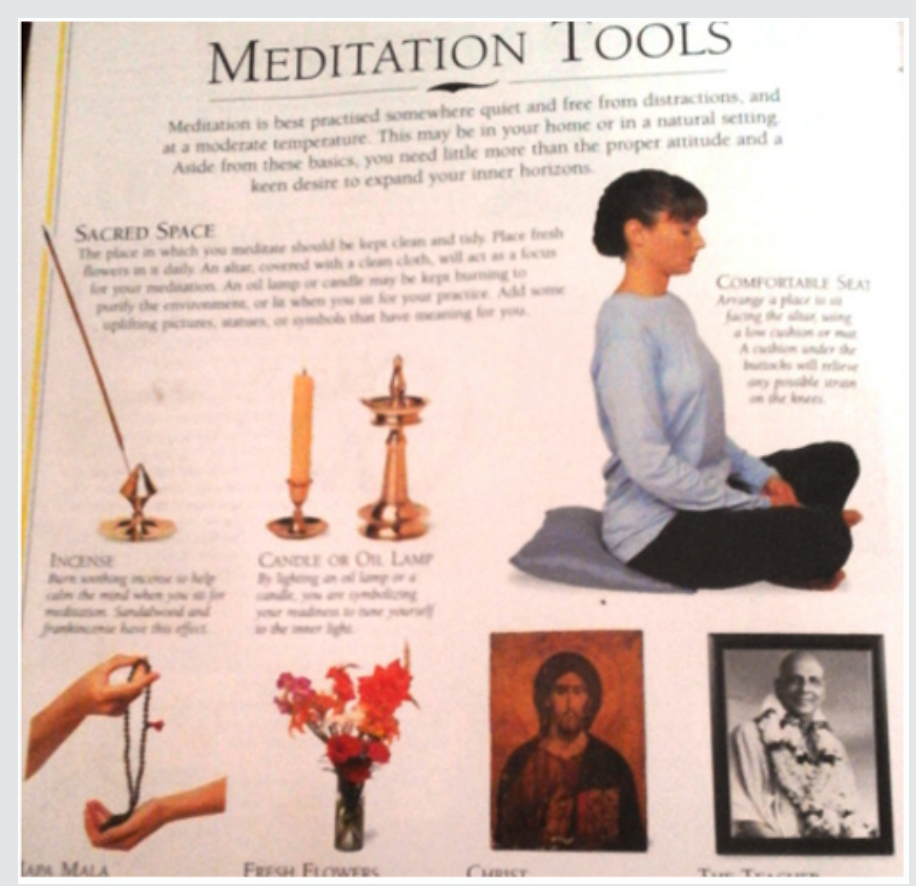

Figure 5: Meditation Tools.

Meditation in the Tiantai school; Tiantai śamathavipaśyanā

In China it has been traditionally held that the meditation methods used by the Tiantai school are the most systematic and comprehensive of all [61]. In addition to its doctrinal basis in Indian Buddhist texts, the Tiantai school also emphasizes use of its own meditation texts which emphasize the principles of samatha and vipaśyanā. Of these texts, Zhiyi’s Concise Śamathavipaśyanā, MoheZhiguan (Sanskrit Mahāśamathavipaśyanā),

and Six Subtle Dharma Gates are the most widely read in China. Rujun Wu identifies the work Mahā-śamatha-vipaśyanā of Zhiyi as the seminal meditation text of the Tiantai school [62]. Regarding the functions of śamatha and vipaśyanā in meditation, Zhiyi writes in his work Concise Śamatha-vipaśyanā: The attainment of Nirvāna is realizable by many methods whose essentials do not go beyond the practice of śamatha and vipaśyanā. Śamatha is the first step to untie all bonds and vipaśyanā is essential to root out delusion Figure 6. Śamatha provides nourishment for the preservation of the knowing mind, and vipaśyanā is the skillful art of promoting spiritual understanding. Śamatha is the unsurpassed cause of samādhi, while vipaśyanā begets wisdom [63]. The Tiantai school also places a great emphasis on ānāpānasmṛti, or mindfulness of breathing, in accordance with the principles of śamatha and vipaśyanā. Zhiyi classifies breathing into four main categories: panting, unhurried breathing, deep and quiet breathing, and stillness or rest. Zhiyi holds that the first three kinds of breathing are incorrect, while the fourth is correct, and that the breathing should reach stillness and rest [64]. Zhiyi also outlines four kinds of samadhi in his Mohe Zhiguan, and ten modes of practicing vipaśyanā Figure 7. 

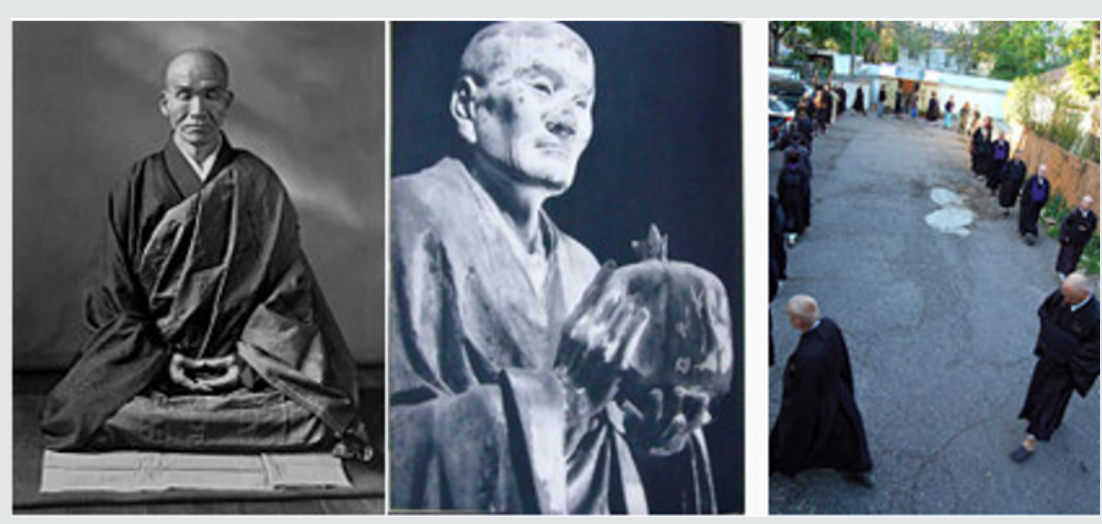

Figure 6: In Mahāyāna Buddhism ,Members of Kanzeon Zen Center during walking meditation.
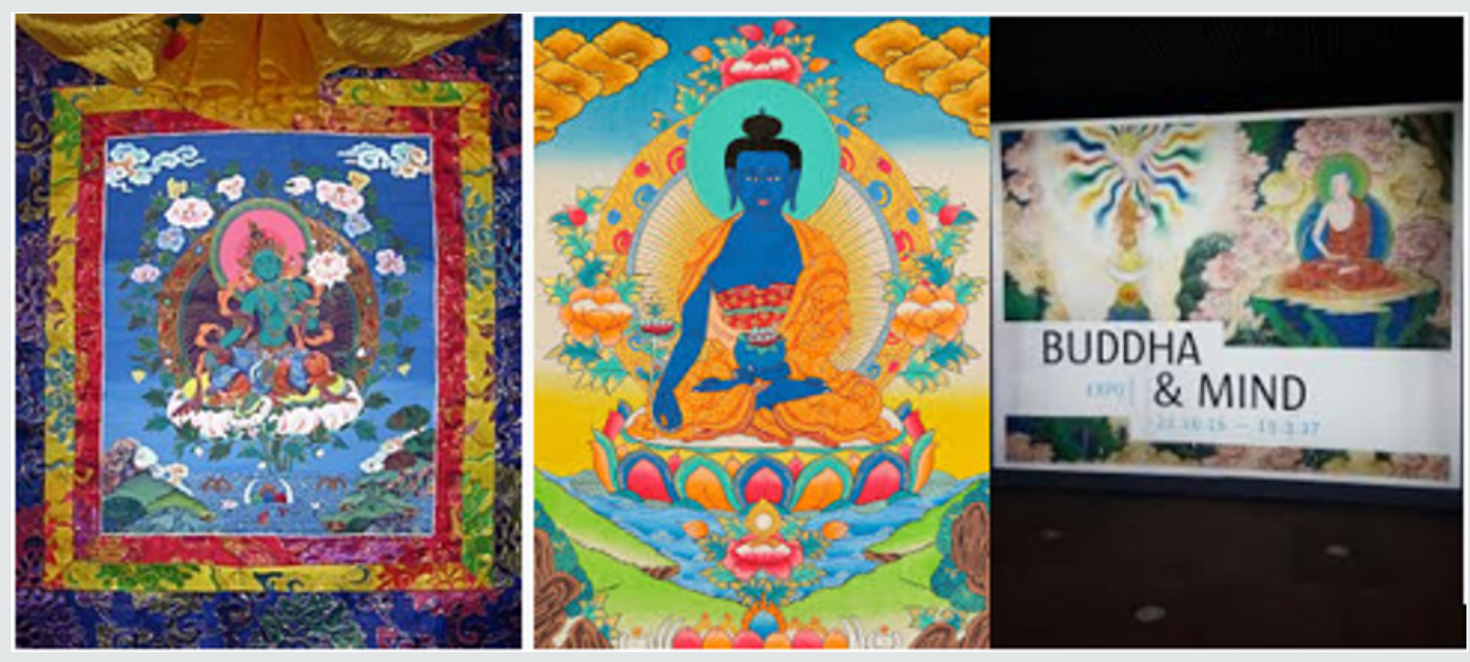

Figure 7: Meditation in Vajrayana Buddhism.

\section{Esoteric Practices in Japan}

One of the adaptations by the Japanese Tendai school was the introduction of Mikkyō (esoteric practices) into Buddhism, which was later named Taimitsu by Ennin. Eventually, according to Tendai Taimitsu doctrine, the esoteric rituals came to be considered of equal importance with the exoteric teachings of the Lotus Sutra. Therefore, by chanting mantras, maintaining mudras, or performing certain meditations, one is able to see that the sense experiences are the teachings of Buddha, have faith that one is inherently an enlightened being, and one can attain enlightenment within this very body. The origins of Taimitsu are found in China, similar to the lineage that Kūkai encountered in his visit to Tang China and Saichō's disciples were encouraged to study under Kūkai [65]. Meditation through the use of complex guided imagery based on Buddhist deities like Tara is a key practice in Vajrayana. Visual aids such as this thangka are often used.

\section{Tantra Techniques (Vajrayana)}

Vajrayana Buddhism includes all of the traditional forms of Mahayana meditation and also several unique forms. The central defining form of Vajrayana meditation is Deity Yoga (devatayoga) [66].This involvesthe recitation of mantras, prayersand visualization of the yidam or deity along with the associated mandala of the deityss Pure Land [67] . Advanced Deity Yoga involves imagining yourself as the deity. Other forms of meditation in Vajayana include the Mahamudra and Dzogchen teachings, each taught by the Kagyu and Nyingma lineages of Tibetan Buddhism respectively. The goal of these is to familiarize oneself with the ultimate nature of mind which underlies all existence, the Dharmakāya. There are also other practices such as Dream Yoga, Tummo, the yoga of the intermediate state (at death) or Bardo, sexual yoga and Chöd. The shared preliminary practices of Tibetan Buddhism are called ngöndro, which involves visualization, mantra recitation, and many prostrations.

\section{Therapeutic uses of Meditation: Mindfulness}

For a long time people have practiced meditation, based on Buddhist meditation principles, in order to effect mundane and worldly benefit [68]. As such, mindfulness and other Buddhist meditation techniques are being advocated in the West by innovative psychologists and expert Buddhist meditation teachers such as Thích Nhất Hạnh, Pema Chödrön, Clive Sherlock, Mya Thwin SN Goenka, Jon Kabat-Zinn, Jack Kornfield, Joseph Goldstein, Tara Brach, Alan Clements, and Sharon Salzberg, who have been widely attributed with playing a significant role in integrating the healing aspects of Buddhist meditation practices with the concept of psychological awareness, healing, and well-being. Although 
mindfulness meditation [69] has received the most research attention, loving kindness [70] (metta) and equanimity [71] (upekkha) meditation are beginning to be used in a wide array of research in the fields of psychology and neuroscience. The accounts of meditative states in the Buddhist texts are in some regards free of dogma, so much so that the Buddhist scheme has been adopted by Western psychologists attempting to describe the phenomenon of meditation in general. ${ }^{[\mathrm{k}]}$ However, it is exceedingly common to encounter the Buddha describing meditative states involving the attainment of such magical powers (Sanskrit rddhi, Pali iddhi) as the ability to multiply one's body into many and into one again, appear and vanish at will, pass through solid objects as if space, rise and sink in the ground as if in water, walking on water as if land, fly through the skies, touching anything at any distance (even the moon or sun), and travel to other worlds (like the world of Brahma) with or without the body, among other things, [72-74] and for this reason the whole of the Buddhist tradition may not be adaptable to a secular context, unless these magical powers are seen as metaphorical representations of powerful internal states that conceptual descriptions could not do justice to Table 2 .

Table 2: Key Terms.

\begin{tabular}{|c|c|c|c|c|}
\hline English & Pali & Sanskrit & Chinese & Tibetan \\
\hline mindfulness/awareness & sati & smṛti & Idea(niàn) & trenpa (wylie: dran pa) \\
\hline clear comprehension & sampajañña & samprajaña & $\begin{array}{l}\text { Correct intelligence (zhèng } \\
\text { zhī lì) }\end{array}$ & shezhin (shes bzhin) \\
\hline vigilance/heedfulness & appamada & apramāda & Do not rest (bù fàng yì zuò) & bakyö (bag yod) \\
\hline ardency & atappa & ātapạ̣ & Brave (yǒng měng) & nyima (nyi ma) \\
\hline attention/engagement & manasikara & manaskāraḥ & Reasonable (rú lǐ zuò yì) & yila jepa (yid la byed pa) \\
\hline foundation of mindfulness & satipațțhāna & smṛtyupasthāna & Remember (niànzhù) & $\begin{array}{c}\text { trenpa neybar zhagpa (dran } \\
\text { pa nye bar gzhag pa) }\end{array}$ \\
\hline mindfulness of breathing & ānāpānasati & ānāpānasmṛti & Anana (ānnàbānnà) & wūk trenpa (dbugs dran pa) \\
\hline calm abiding/cessation & samatha & śamatha & stop(zhǐ) & shiney (zhi gnas) \\
\hline insight/contemplation & vipassanā & vipaśyanā & View (guān) & lhagthong (lhag mthong) \\
\hline meditative concentration & samādhi & samādhi & Misery (sānmèi) & $\begin{array}{l}\text { ting-nge-dzin (ting nge } \\
\text { dzin) }\end{array}$ \\
\hline meditative absorption & jhāna & dhyāna & Zen (chán) & samten (bsam gtan) \\
\hline cultivation & bhāvanā & bhāvanā & Practice (xiūxíng) & gompa (sgom pa) \\
\hline cultivation of analysis & Vitakka and Vicāra & *vicāra-bhāvanā & $\begin{array}{l}\text { Looking for an inspection } \\
\text { (xún sì chá) }\end{array}$ & chegom (dpyad sgom) \\
\hline cultivation of settling & - & *sthāpya-bhāvanā & - & jokgom ('jog sgom) \\
\hline
\end{tabular}

\section{Theravada Buddhist meditation practices}

a) Anapanasati - focusing on the breath

b) Satipatthana - Mindfulness of body, sensations, mind and mental phenomena

c) The Four Immeasurables - including compassion karuna and loving-kindness Metta
d) Kammațțāna
e) Buddhānusmṛti - devotional meditation
f) Samatha - calm abiding
g) Vipassana - insight
h) Mahasati Meditation
i) Dhammakaya Meditation

\section{Zen Buddhist meditation practices}
a) Shikantaza - just sitting
b) Kinhin
c) Zazen
d) Koan

e) Hua Tou

f) Suizen (historically practiced by the Fuke sect)

\section{Buddhist meditation centers}

a) Insight Meditation Society - Insight meditation, Barre, Massachusetts, United States

b) Dharma Drum Retreat Center - Ch'an/Zen Buddhist meditation center in Pine Bush, New York, United States

c) Padmaloka Buddhist Retreat Centre Triratna center for men in Norfolk, UK

d) Chapin Mill Zen Buddhist meditation center in Rochester, New York, United States

e) Furnace Mountain Zen Buddhist meditation center in Kentucky, United States

f) San Francisco Zen Center

\section{Vajrayana and Tibetan Buddhist Meditation Practices}

a) Deity yoga

b) Ngondro - preliminary practices

c) Tonglen - giving and receiving 
d) Phowa - transference of consciousness at the time of death

e) Chöd - cutting through fear by confronting it

f) Mahamudra - the Kagyu version of 'entering the allpervading Dharmadatu', the 'nondual state', or the 'absorption state'

g) Dzogchen - the natural state, the Nyingma version of Mahamudra

h) The Four Immeasurables, Metta

i) Tantra techniques

\section{Related Buddhist practices}

a) Mindfulness - awareness in the present moment

b) Mindfulness (psychology) - Western applications of Buddhist ideas

c) Satipatthana

d) chanting and mantra

Proper floor-sitting postures and supports while meditating:

a) Floor sitting: cross-legged (full lotus, half lotus, Burmese) or seiza

b) Cushions: zafu, zabuton

\section{Traditional Buddhist texts on meditation}

a) Anapanasati Sutta

b) Satipatthana Sutta

c) Buddhaghosa's Visuddhimagga - 'The path of Purification', used in Theravada Buddhism

d) Kamalashila's Bhāvanākrama - 'Stages of meditation', used in Tibetan Buddhism

e) Zhiyi's Great Concentration and Insight (Mohe Zhiguan) used in the Chinese Tiantai school

f) Seventeen tantras - Major Tibetan Dzogchen texts

g) The Wangchuk Dorje's "Ocean of Definitive Meaning", major text on Mahamudra meditation.

h) Dakpo Tashi Namgyal's "Mahamudra: The Moonlight Quintessence of Mind and Meditation"

i) Fukan-zazengi - By Dogen, used in the Japanese Soto Zen school

\section{Traditional preliminary practices to Buddhist meditation}
a) prostrations (also see Ngondro)
b) refuge in the Triple Gem
c) Five Precepts

\section{Analog in Vedas}
a) Dhyana in Hinduism
b) Ksirodakasayi Vishnu
c) Paramatma

\section{Analog in Taoism}
a) Daoist meditation
b) Internal alchemy

\section{Notes}

Forinstance, Kamalashila(2003) states thatBuddhistmeditation "includes any method of meditation that has Enlightenment as its ultimate aim.» Likewise, Bodhi (1999) writes: "To arrive at the experiential realization of the truths it is necessary to take up the practice of meditation.... At the climax of such contemplation the mental eye ... shifts its focus to the unconditioned state, Nibbana...." A similar although in some ways slightly broader definition is provided by Fischer-Schreiber et al. (1991). "Meditation - general term for a multitude of religious practices, often quite different in method, but all having the same goal: to bring the consciousness of the practitioner to a state in which he can come to an experience of 'awakening,' 'liberation,' 'enlightenment.'Kamalashila (2003) further allows that some Buddhist meditations are "of a more preparatory nature" . The Pali and Sanskrit word bhāvanā literally means «development» as in "mental development.» For the association of this term with «meditation," see Epstein (1995) and, Fischer-Schreiber et al. (1991). As an example from a wellknown discourse of the Pāli Canon, in "The Greater Exhortation to Ranula" (Maha-Rahulovada Sutta, MN 62), Sariputta tells Rahula (in Pali, based on VRI, n.d.): ānāp ānassatim, rāhula, bhāvanaṃ bhāvehi. Thanissaro (2006) translates this as: «Rahula, develop the meditation [bhāvana] of mindfulness of in-\&-out breathing." (Square-bracketed Pali word included based on Thanissaro, 2006, end note.) See, for example, Rhys Davids \& Stede (1921-25), entry for "jhāna";"; Thanissaro (1997); as well as, Kapleau (1989) for the derivation of the word "zen" from Sanskrit «dhyāna." PTS Secretary Dr. Rupert Gethin, in describing the activities of wandering ascetics contemporaneous with the Buddha, wrote: T] cultivation of meditative and contemplative techniques aimed at producing what might, for the lack of a suitable technical term in English, be referred to as (altered states of consciousness). In the technical vocabulary of Indian religious texts, such states come to be termed (meditations` (Sanskrit: dhyāna, Pali: jhāna) or 'concentrations' (samādhi); the attainment of such states of consciousness was generally regarded as bringing the practitioner to deeper knowledge and experience of the nature of the world." (Gethin 1998) The analysis and interpretation the data based on qualitative variables as follows; The study clearly indicates that majority business management graduates get physical advantages of Vipassana Meditation process, in one way or other. Major benefits includes understanding of hidden potentials $(20.3 \%)$, ability to withstand pain (15\%), flexibility of physique, $(12.8 \%)$, 
positive feeling (11.3), increased concentration (6\%) etc. Students obtained different advantages by undergoing this awareness process. The study indicates that majority business management student get psychological benefits out of the Vipassana Meditation Process. Among the Psychological benefits 36.2\% of students reported that they obtained peace and stability of mind, strong will power, become calm, quiet, and relaxed. They could be able to understand the strength and weaknesses, and become more composed, compassionate, determined, developed and developed the feeling equanimity. Their ability to concentrate day to day classes increased $(24.1 \%)$ and gained better control over anger, agitation, frustration, reaction formation and hyper activeness (22.6\%). Students obtained different psychological advantages by undergoing awareness process. A very few students reported (3\%) no change in their behaviour. Goldstein (2003) writes that, in regard to the Satipatthana Sutta, "there are more than fifty different practices outlined in this Sutta. The meditations that derive from these foundations of mindfulness are called vipassana..., and in one form or another - and by whatever name - are found in all the major Buddhist traditions". The forty concentrative meditation subjects refer to Visuddhimagga's oft-referenced enumeration. Regarding Tibetan visualizations, Kamalashila (2003), writes: "The Tara meditation ... is one example out of thousands of subjects for visualization meditation, each one arising out of some meditator's visionary experience of enlightened qualities, seen in the form of Buddhas and Bodhisattvas" Table 3.

Table 3: Physical Advantages of Vipassana.

\begin{tabular}{|c|c|c|c|}
\hline \multirow{2}{*}{$\begin{array}{l}\text { Sl. } \\
\text { No. }\end{array}$} & \multirow{2}{*}{ Physical Advantage of Vipassana } & \multicolumn{2}{|c|}{ Students } \\
\hline & & $\mathbf{N}$ & $\%$ \\
\hline 1 & $\begin{array}{l}\text { Understand ones own hidden strength and } \\
\text { potential. }\end{array}$ & 27 & 20.3 \\
\hline 2 & $\begin{array}{l}\text { Reduced Anxiety about food (One meal is } \\
\text { enough in one day) }\end{array}$ & 2 & 1.5 \\
\hline 3 & Body becomes more flexible. & 17 & 12.8 \\
\hline 4 & Physical level resistance increased & 2 & 1.5 \\
\hline 5 & Aware of healthy diet & 3 & 2.3 \\
\hline 6 & Efficiency of digestive system increased. & 3 & 2.3 \\
\hline 7 & $\begin{array}{l}\text { Get rid of too much addiction of tea having } \\
\text { habit }\end{array}$ & 2 & 1.5 \\
\hline 8 & Increased energy level & 3 & 2.3 \\
\hline 9 & Feel healthy and fresh & 15 & 11.3 \\
\hline 10 & Reduced body weight & 4 & 3 \\
\hline 11 & Better breathing & 2 & 1.5 \\
\hline 12 & Early wake up and early bed habit attained & 2 & 1.5 \\
\hline 13 & Increased concentration & 8 & 6 \\
\hline 14 & Ability to withstand pain & 15 & 11.3 \\
\hline 15 & No back pain & 1 & 0.8 \\
\hline \multirow[t]{2}{*}{16} & Leg pain subsided & 1 & 0.8 \\
\hline & Total & 133 & 100 \\
\hline
\end{tabular}

Examples of contemporary school-specific "classics" include, from theTheravada tradition, Nyanaponika (1996) and, from the Zen tradition, Kapleau (1989). For instance, from the Pāli Canon, see MN 44 (Thanissaro, 1998a) and AN 3:88 (Thanissaro, 1998b).
In Mahayana tradition, the Lotus Sutra lists the Six Perfections (pāramitā) which echoes the threefold training with the inclusion of virtue (śîla), concentration (samadhi) and wisdom (prajñā). For example, Bodhi (1999), in discussing a latter stage of developing Right View (that of "penetrating" the Four Noble Truths), states: To arrive at the experiential realization of the truths it is necessary to take up the practice of meditation - first to strengthen the capacity for sustained concentration, then to develop insight. These definitions of samatha and vipassana are based on the "Four Kinds of Persons Sutta" (AN 4.94). This article's text is primarily based on Bodhi (2005), See also Thanissaro (1998d). Bodhi (2000) See also Thanissaro (1998c) (where this sutta is identified as SN 35.204). See also, for instance, a discourse (Pali: sutta) entitled, "Serenity and Insight" (SN 43.2), where the Buddha states: "And what, bhikkhus, is the path leading to the unconditioned? Serenity and insight...." (Bodhi, 2000). When [the Pali discourses] depict the Buddha telling his disciples to go meditate, they never quote him as saying 'go do vipassana,' but always 'go do jhana.' And they never equate the word vipassana with any mindfulness techniques. In the few instances where they do mention vipassana, they almost always pair it with samatha - not as two alternative methods, but as two qualities of mind that a person may 'gain' or 'be endowed with,' and that should be developed together. Similarly, referencing MN 151, vv. 13-19, and AN IV, 125-27, Ajahn Brahm (who, like Bhikkhu Thanissaro, is of the Thai Forest Tradition) writes: Some traditions speak of two types of meditation, insight meditation (vipassana) and calm meditation (samatha). In fact, the two are indivisible facets of the same process. Calm is the peaceful happiness born of meditation; insight is the clear understanding born of the same meditation. Calm leads to insight and insight leads to calm. (Brahm 2006) Michael Carrithers, (The Buddha 1983) Found in Founders of Faith, Oxford University Press, 1986. The author is referring to Pali literature. See however B. Alan Wallace, the bridge of quiescence: experiencing Tibetan Buddhist meditation. Carus Publishing Company, 1998, where the author demonstrates similar approaches to analyzing meditation within the Indo-Tibetan and Theravada traditions Table 4.

Table 4: Psychological Advantage of Vipassana.

\begin{tabular}{|c|c|c|c|}
\hline \multirow{2}{*}{$\begin{array}{c}\text { Sl. } \\
\text { No. }\end{array}$} & Psychological Advantage of Vipassana & \multicolumn{2}{|c|}{ Students } \\
\cline { 3 - 4 } 1 & N & \% \\
\hline & $\begin{array}{c}\text { Get peace and stability of mind, strong will power, } \\
\text { become calm, quite, relaxed, understand strength } \\
\text { and weaknesses, become composed, patience, } \\
\text { compassionate, determined, feeling equanimity. }\end{array}$ & 48 & 36.2 \\
\hline 4 & $\begin{array}{c}\text { Better positive thinking, objective out look, } \\
\text { intellectually refined, Higher level of happiness }\end{array}$ & 14 & 10.6 \\
\hline 5 & $\begin{array}{c}\text { Control over, tension, agitation, anger, frustration } \\
\text { reactions, hyper activeness. }\end{array}$ & 30 & 22.6 \\
\hline 9 & Better decision making & 2 & 1.5 \\
\hline 11 & Can concentrate more on the class, & 32 & 24.1 \\
\hline 12 & $\begin{array}{c}\text { Free from the habits of sleeping inside the class } \\
\text { room }\end{array}$ & 2 & 1.5 \\
\hline 13 & Just as before, No benefit, & 4 & 3 \\
\hline 14 & $\begin{array}{c}\text { Could take responsibility of many unjustifiable past } \\
\text { events }\end{array}$ & 1 & 0.8 \\
\hline & Total & 133 & 100 \\
\hline
\end{tabular}




\section{References}

1. Anālayo (2017) Early Buddhist Meditation Studies, pp. 165.

2. Wynne Alexander (2007) The origin of Buddhist meditation. 23: 37-192.

3. Bronkhorst Johannes (1993) The two traditions of meditation in Ancient India, ( $\left.2^{\text {nd }} e d n\right)$ : Delhi: Motilal Banarsidass, pp. 10-164.

4. BCD Bronkhorst (2012) Johannes. Early Buddhist Meditation. (paper presented at the conference "Buddhist Meditation from Ancient India to Modern Asia", Jogye Order International Conference Hall, Seoul)

5. Wynne Alexander, The origin of Buddhist meditation, p. 94-95.

6. Wynne Alexander, The origin of Buddhist meditation, p. 95.

7. Dharmacarini Manishini/Alice Collett (1921) Kamma in Context: The Mahakammavibhangasutta and the Culakammavibhangasutta 4: 1-24.

8. (1999) See for instance, Bodhi.

9. (2005) See for instance, AN 2.30 in Bodhi, pp. 267-68.

10. (2005) Bodhi. pp. 268.

11. (1999) See for instance, Bodhi and Nyanaponika. pp. 108.

12. Vetter Tilmann (1988) The Ideas and Meditative Practices of Early Buddhism. BRILL, pp: 1-107.

13. Bronkhorst Johannes (1993) The Two Traditions Of Meditation In Ancient India. Motilal Banarsidass Publ.

14. Anālayo (2017) Early Buddhist Meditation Studies. Barre Center for Buddhist Studies Barre, Massachusetts. pp. 109.

15. Anālayo (2017) Early Buddhist Meditation Studies, Barre Center for Buddhist Studies Barre, Massachusetts. pp: 112-115.

16. Anālayo (2017) Early Buddhist Meditation Studies, Barre Center for Buddhist Studies Barre, Massachusetts. pp: 117.

17. Edward Fitzpatrick Crangle (1994) The Origin and Development of Early Indian Contemplative Practices, pp: 1-238.

18. (2007) Should We Come Out of jhāna to Practice vipassanā? in Buddhist Studies in Honour of Venerable Kirindigalle Dhammaratana, S. Ratnayaka (Eds.), p. 41-74.

19. Shankman Richard (2008) The Experience of samādhi, An Indepth Exploration of Buddhist Meditation, Boston: Shambala.

20. Anālayo (2017) Early Buddhist Meditation Studies, Barre Center for Buddhist Studies Barre, Massachusetts, USA, pp: 123

21. From Teaching Dhamma by pictures: Explanation of a Siamese Traditional Buddhist Manuscript.

22. Bhikkhu Sujato, A History of Mindfulness How insight worsted tranquillity in the Satipațțhāna Sutta, Santipada, pp: 148.

23. Bhikkhu Sujato (2005) A History of Mindfulness How insight worsted tranquillity in the Satipatthāna Sutta, Santipada, pp. 148.

24. (1986) For instance. see Solé-Leris, p. 75.

25. Anālayo (2017) Early Buddhist Meditation Studies, Barre Center for Buddhist Studies Barre, Massachusetts, USA, pp: 185.

26. Merv Fowler (1999) Buddhism: Beliefs and Practices. Sussex Academic Press. p. 60-62.

27. Peter Harvey (2012) An Introduction to Buddhism: Teachings, History and Practices. Cambridge University Press, UK. pp. 154-326.

28. Anālayo (2017) Early Buddhist Meditation Studies, Barre Center for Buddhist Studies Barre, Massachusetts, USA. pp. 186.

29. Anālayo (2017) Early Buddhist Meditation Studies, Barre Center for Buddhist Studies Barre, Massachusetts, USA. pp. 194.

30. PV Bapat (1937) Vimuttimagga \& Visuddhimagga - A Comparative Study.
31. Sarah Shaw (2006) Buddhist meditation: An anthology of texts from the Pāli canon. Routledge. p. 6-8.

32. PV Bapat (1937) Vimuttimagga \& Visuddhimagga - A Comparative Study.

33. (1999) Buddhaghosa \& Nanamoli. p. 85-90.

34. (1999) Buddhaghoșa \& Nanamoli. pp. 110.

35. (1988) Regarding the jhanic attainments that are possible with different meditation techniques. see Gunaratana.

36. Crosby Kate (2013) Theravada Buddhism: Continuity, Diversity, and Identity. John Wiley \& Sons, USA.

37. Tiyavanich K (1997) Forest Recollections: Wandering Monks in Twentieth Century Thailand. University of Hawaii Press, USA.

38. Newell Catherine (2011) Two Meditation Traditions from Contemporary Thailand: A Summary Overview. Rian Thai : International Journal of Thai Studies 4: 81-110.

39. Suen Stephen (2009) Methods of spiritual praxis in the Sarvāstivāda: A Study Primarily Based on the Abhidharma-mahāvibhāṣā. The University of Hong Kong, Hong Kong, p. 67.

40. Bhikkhu KL Dhammajoti, Sarvāstivāda-Abhidharma (2007) Centre of Buddhist Studies the University of Hong Kong, Hong Kong, pp: 575-576.

41. Suen Stephen (2009) Methods of spiritual praxis in the Sarvāstivāda: A Study Primarily Based on the Abhidharma-mahāvibhāṣā. The University of Hong Kong, Hong Kong, pp: 177.

42. Suen Stephen (2009) Methods of spiritual praxis in the Sarvāstivāda: A Study Primarily Based on the Abhidharma-mahāvibhāṣā. The University of Hong Kong, Hong Kong, pp. 191.

43. Bhikkhu KL Dhammajoti, Sarvāstivāda Abhidharma (2007) Centre of Buddhist Studies The University of Hong Kong, Hong Kong, pp: 575-576.

44. Bhikkhu KL Dhammajoti, Sarvāstivāda-Abhidharma (2007) Centre of Buddhist Studies The University of Hong Kong, Hong Kong, pp. 577.

45. Luk Charles (1964) The Secrets of Chinese Meditation, p. 11.

46. Nan Huai-Chin (1994) To Realize Enlightenment: Practice of the Cultivation Path, p. 1.

47. Delenau Florin (2013) Buddhist Meditation in the Bodhisattvabhumi.

48. Deleanu Florin (1992) Mindfulness of Breathing in the Dhyāna Sūtras. Transactions of the International Conference of Orientalists in Japan (TICOJ) 37: 42-57.

49. Bhante Dhammadipa (2015) kumārajīva's Meditative Legacy in China.

50. Luk Charles (1964) The Secrets of Chinese Meditation. p. 83.

51. Luk Charles (1964) The Secrets of Chinese Meditation. p. 84.

52. Yuan Margaret (1986) Grass Mountain: A Seven Day Intensive in Ch'an Training with Master Nan Huai-Chin. p. 55.

53. Luk Charles (1964) The Secrets of Chinese Meditation. p. 85.

54. Luk Charles (1964) The Secrets of Chinese Meditation. p. 44.

55. Nan, Huai Chin (1997) Basic Buddhism: Exploring Buddhism and Zen. p. 92

56. Yuan Margaret (1986) Grass Mountain: A Seven Day Intensive in Ch'an Training with Master Nan Huai-Chin. p. 2.

57. Luk Charles (1964) The Secrets of Chinese Meditation. p. 45.

58. Hsuan Hua (2004) The Chan Handbook. p. 47.

59. Luk Charles (1964) The Secrets of Chinese Meditation. p. 49.

60. Luk Charles (1964) The Secrets of Chinese Meditation. p. 48.

61. Luk Charles (1964) The Secrets of Chinese Meditation. pp. 110. 
62. Wu Rujun (1993) T'ien-t'ai Buddhism and Early Mādhyamika. University of Hawaii Press, USA.

63. Luk Charles (1964) The Secrets of Chinese Meditation. pp. 111.

64. Luk Charles (1964) The Secrets of Chinese Meditation. pp. 125.

65. Abe Ryūichi (2013) The Weaving of Mantra: Kūkai and the Construction of Esoteric Buddhist Discourse. Columbia University Press, USA.

66. Power John (2007) Introduction to Tibetan Buddhism. pp. 271.

67. Garson Nathaniel DeWitt (2004) Penetrating the Secret Essence Tantra: Context and Philosophy in the Mahayoga System of rNying-ma Tantra, p. 37.

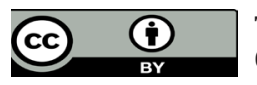

This work is licensed under Creative Commons Attribution 4.0 License

To Submit Your Article Click Here:

Submit Article

DOI: $10.32474 /$ SJPBS.2019.02.000140
68. See, for instance, Zongmi's description of bonpu and gedō zen, described further below.

\section{MARC UCLA}

70. Hutcherson Cendri (2008) Loving-Kindness Meditation Increases Social Connectedness. 8(5): 720-724.

71. Brahmana Metteyya (2008) New Equanimity Meditation and Tools from Psychology to Test Its Effectiveness.

72. Iddhipada-vibhanga Sutta.

73. Samañ̃̃aphala Sutta.

74. Kevatta Sutta.

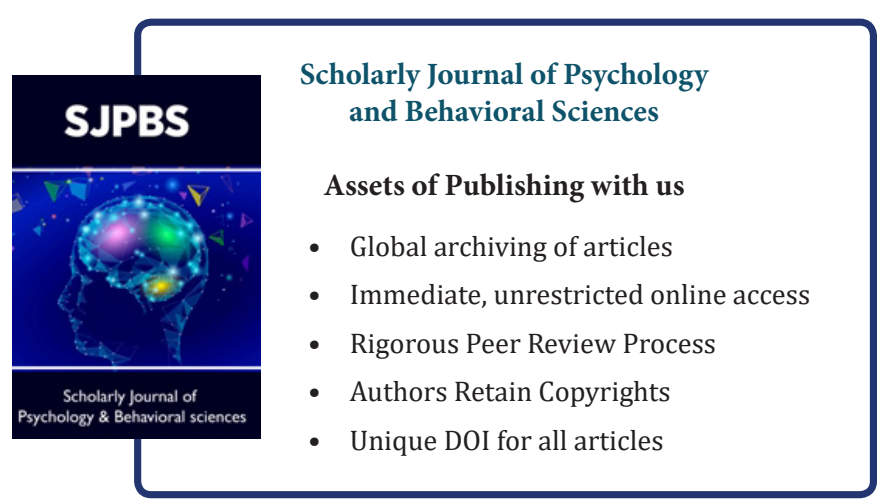

